\title{
Recepcija hrvatskih filozofa i digitalna humanistika
}

\section{Abstract: The Reception of Croatian Philosophers and Digital Humanities}

This paper discusses links between digital humanities and philosophy, which have been connected for a long time. The paper focuses on the representation of Croatian philosophers in specialized encyclopedias and dictionaries. Main areas at the intersection of the two disciplines are targeted: generating repositories, creating social networks for experts, and new approaches to analyzing digitalized content. In this context, the paper analyzes the (under-)representation of several Croatian philosophers in tertiary sources. The results show that the number of philosophers with name entries in encyclopedias is small, that the number of languages for the existing articles is also small, and that there are certain inaccuracies in those articles. Finally, the paper suggests certain procedures to remedy the present condition.[1]

Keywords: digital humanities, national philosophies, encyclopedia, dictionary

\section{Uvod}

Unutar humanistike posljednjih je godina očit pomak u metodologiji, te dijelom i u predmetu istraživanja, prema digitalnoj ili računalnoj humanistici (humanities computing) koji se očituje širim korpusom istraživanja rabeći nove resurse i alate (Nikolić 76). Nove tehnologije omogućuju pristup bazama informacija, povećavaju mogućnosti korištenja informacija i njihovo razumijevanje. Također, zahvaljujući novim tehnologijama, otvaraju se novi oblici znanstvene komunikacije i suradnje te se poboljšava diseminacija znanja. Digitalna tehnologija olakšava pretraživanje i prikupljanje dokumenata, razmjenu i širenje znanja, unutar i izvan znanstvenih krugova. Dolazi do 
promjene u istraživačkom procesu u korist sekundarnih izvora te tekstovi, kao primarni izvori, ustupaju mjesto vizualnosti i zvuku mijenjajući „mentalne navike“ u humanističkim znanostima, pri čemu se razvijaju novi „hibridni načini komuniciranja“ (Schnapp i Presner 2).

Vidljive su jasne promjene paradigme istraživanja u humanističkim znanostima pod utjecajem digitalne tehnologije: „Pomiču se granice između humanistike, društvenih znanosti, umjetnosti i prirodnih znanosti; istraživanja su vezana uz projekte i suradnička okruženja; razvijaju se projekti koji proširuju značenje, poboljšavaju kakvoću i povećavaju vidljivost istraživanja u humanistici; primjenjuju se kvantitativne metode“ (Tomić 12). Zanimljiv je primjer sukoba između znanstvenika iz humanističkih znanosti i knjižnice na Sveučilištu u Syracuseu iz 2009, kada su zaposlenici iz knjižnice priopćili kako žele osloboditi prostor u knjižnici i uštedjeti novac slanjem dijela građe na udaljenu lokaciju. Profesori humanističkih znanosti glasno su se pobunili dajući do znanja da knjižnicu smatraju svojim „središnjim laboratorijem“ (Howard). Iz ovog se može zaključiti kako humanisti istraživačku građu pronalaze u knjižnicama, muzejima, arhivima. Ta je situacija izvjesno u korelaciji s provedenim istraživanjima koja svjedoče o niskom korištenju računalnih alata i IT-a općenito među istraživačima iz područja humanistike u razdoblju 90-ih do ranih 2000-ih (Tomić 14). Nikolić također konstatira da na hrvatskim studijima filologije postoji nedostatak temeljnog obrazovanja u kvantitativnom i računalnom pristupu tekstovima. Nikolić također konstatira da na hrvatskim studijima filologije postoji nedostatak temeljnog obrazovanja u kvantitativnome i računalnome pristupu tekstovima (84).

Narativi razvoja digitalne humanistike u raznim disciplinama: arheologiji (Eiteljorg), povijesti umjetnosti (Greenhalgh), klasičnoj književnosti (Crane) ili leksikografiji (Woolridge) pokazuju sličan obrazac interakcije. Prvu fazu čini digitalizacija materijala i njihova olakšana diseminacija. Drugu predstavlja olakšavanje komunikacije među stručnjacima u polju, isprva putem e-mail lista. Treću fazu predstavlja analiza sadržaja i otkrivanje skrivenih struktura. Na sličnom je tragu i identificiranje triju perspektiva u digitalnoj humanistici: tehnološke minijaturizacije, tekstualne informatike te informacijske hermeneutike (Busa xvi-xviii).

\section{Digitalna humanistika i filozofija}


Digitalna humanistika i filozofija imaju dugu zajedničku povijest. Počeci sežu do 1945. godine i projekt Roberta Buse Index Thomisticum (Hockey 4). Projekt je prolazio kroz tehnološke - od bušenih kartica, preko magnetskih traka do pohrane na DVD i metodološke transformacije - od prebrojavanja riječi i kolokacija do lematizirane konkordancije (Busa xvii).

Na izvjestan način, za filozofiju pojava računala u humanistici nije predstavljala revoluciju područje filozofije uma uvelike se bavilo računalnom metaforom uma i konceptualnim implikacijama takvog pristupa ${ }^{2]}$ (Ess). Dakako, i u filozofiji možemo svjedočiti istim fazama uporabe računala kao i drugim dijelovima humanistike. No, ideja računala kao metafore uma već je bila ustaljena tema u filozofiji uma, a s njom i problemi proceduralne epistemologije (Pollock), računalne, kiber- i informacijske etike, dok je područje filozofije informacije (Floridi), iako novijeg datuma, jednim dijelom iznova postavilo neka klasična pitanja iz filozofije znanosti, oslanjajući se na sveprisutnost računala u suvremenom životu. Pošteđene nisu ostale ni klasične teme poput metafizike (Steinhart) ili povijesti filozofije (Collins).

Ovdje nas zanima enciklopedijska organizacija znanja, napose onoga o filozofiji. Sama ideja enciklopedizma temelji se na „filozofskom poimanju potrebe da se ukupno znanje obuhvati u cjelinu i zatim sistematizira radi lakšeg korištenja“ (Domić Kunić 87). Projekte usustavljivanja cjelokupnog (ili barem značajnog dijela) znanja provodili su filozofi od antike, poput Aristotela ili Plinija, preko srednjovjekovnih enciklopedijskih spisa lucidara (lat. Lucidarius), zatim F. Bacona i Hegelova enciklopedijskog sustava filozofije ili Saint-Simonove hijerarhijske organizacije znanja. XVIII. stoljeće označava početak razdoblja stvaranja velikih enciklopedija: Chambersova Cyclopaedia (1728), Diderotova Encyclopédie (1751), Encyclopaeddia Britannica (1771) i Brockhaus (1818) (Vujić 1213). U XIX. se stoljeću ti pokušaji odmiču od filozofije i polako tvore osnove informacijskih znanosti, discipline zadužene za organizaciju znanja.

Riječ „enciklopedija“ prvi je upotrijebio u današnjem značenju hrvatski humanist P. Skalić u djelu Znalac enciklopedija ili kruga znanosti kako svetih tako i svjetovnih (Encyclopaediae seu orbis disciplinarum tam sacrarum quam profanarum epistemon, 1559) definirajući pojam enciklopedije kao sveukupnost ljudskog znanja (Vujić 12). Enciklopedije u ranijim razdobljima bile su rezultat rada pojedinaca, no industrijski razvoj, prosvjetiteljstvo i razvoj građanskog društva u XVIII. stoljeću donose velike promjene u enciklopedijskom kodificiranju. Enciklopedijski rad postaje kolektivno 
djelo velikog broja suradnika, uz potrebnu institucionalnu podršku i financiranje, što dovodi i do njihove vezanosti za određeno vrijeme i prostor (Vujić 15). Čuvena je Encyclopaedia Britannica u počecima vezana za konzervativne i klerikalne krugove te „sto godina nakon objavljivanja Newtonovih zakona nebeske mehanike (1687) odbacuje njegove zakone gravitacije, a zakon fizike još uvijek tumači 'klasičnim elementom vatre'“ (Vujić 15).

Sustav organizacije znanja unutar enciklopedija ostvaren je u obliku članaka, obično posvećenih nekoj temi, a prati ih osnovna bibliografija te ime autora članka. Znanstvena i industrijska revolucija krajem XIX. stoljeća dostižu svoj puni zamah i šire se na sva područja ljudskog djelovanja.

Pokušaji usustavljivanja znanja počinju se odvajati od filozofije i polako tvore osnove informacijskih znanosti. Sama struktura znanja u enciklopedijama, usporedo s razvojem informacijskih tehnologija, postala je prikladna za objavljivanje u elektroničkom obliku u kojem, u novije doba, enciklopedije uglavnom i postoje. Najstarija i jedna od najuglednijih enciklopedija na engleskom jeziku Encyclopaedia Britannica ne izdaje se više u tiskanom obliku već isključivo u elektroničkom. Nove informacijske tehnologije osigurale su mehanizam za pohranjivanje i distribuciju neograničene količine znanja iz svih područja života (Ravlić 51). Upravo se kroz razvoj novih tehnologija vidi ostvarenje prosvjetiteljskog ideala enciklopedije, odnosno otvoreni pristup znanju koje se kreira u zajednici (Ravlić 53). Uspostavljanje svjetske enciklopedije zagovarao je i Herbert George Wells u svom eseju World Brain: The Idea of a Permanent World Encyclopedia, gdje se zalaže za stvaranje sustava za prikupljanje i oslobađanje znanja koji bi rastao i mijenjao se te bio slobodno dostupan svakom čovjeku (Jecić 107).

Tiskane enciklopedije u XIX. i XX. stoljeću poprimaju nacionalni karakter s ciljem služenja razvoju nacionalne kulture i identiteta (Jecić 106). S druge strane, razvoj novih medija ostvaruje koncept enciklopedije kao „svesvjetskog repozitorija znanja“ (Jecić 108) i jamči enciklopedijama nadnacionalni karakter. Kroz usavršavanje internetskih sustava za prevođenje, očekuje se da se krug korisnika mrežnih enciklopedija širi izvan jezičnih granica dajući im karakter nadnacionalnosti. Primjera radi, Wikipedija je u siječnju 2018. imala izdanje na 298 jezika. Parafrazirajući Wellsa možemo zaključiti da je enciklopedijsko poduzetništvo uhvatilo korak s informacijskim tehnologijama. 


\section{Problem „malih“ znanstvenih zajednica}

Pitanje politike jezika u znanosti i visokom obrazovanju tema je koja izaziva dosta pozornosti u znanstvenim krugovima. Rašireno je mišljenje da engleski jezik predstavlja lingua franca u svim područjima ljudske djelatnosti (Pašalić i Marinov). Engleski jezik dominantan je u području znanosti, tehnologije i financija, a sve kao posljedica globalizacije (Haberland; Gehrmann i Rončević). Ljudi komuniciraju u međunarodnim okvirima i potreban im je alat koji omogućuje brzu razmjenu informacija. No, takav razvoj situacije ostavlja ozbiljne posljedice na male jezike - u sve povezanijem svijetu smanjuju se jezične raznolikosti. Trenutno je u svijetu oko $25 \%$ svjetskih jezika u neposrednoj opasnosti od nestajanja (Amano et al.). Organizacija za obrazovanje, znanost i kulturu pri Ujedinjenim narodima u studenom 1999. godine donijela je odluku o proglašenju 21. veljače Međunarodnim danom materinskog jezika kako bi alarmirala javnost o potrebi očuvanja jezične raznolikosti u svijetu kao svjetske baštine. Dvije godine kasnije usvojena je i Deklaracija o kulturnoj različitosti koja naglašava kako se „svakoj osobi mora omogućiti izražavanje i stvaranje djela na jeziku koji izabere, posebice na materinskome jeziku“ (UNESCO čl. 5). U sklopu međunarodnog obilježavanja jezične raznolikosti 2015. godina posvećena je ulozi lokalnih jezika u napretku znanosti s ciljem bržeg širenja novih znanstvenih spoznaja.

Svaka država nastoji očuvati nacionalni identitet, a jezik je „dio identiteta, čovjeka kao pojedinca i čovjeka kao dijela društva“ (Miloš 12). Tako je i u Strategiji obrazovanja, znanosti i tehnologije RH naznačeno da u vrijeme globalizacije „u kojemu je na djelu snažno miješanje različitih kultura, svjetonazora i religija - čovjek treba postati građaninom svijeta, a pritom sačuvati svoj nacionalni identitet, svoju kulturu, kulturne krajolike, društvenu, moralnu i duhovnu baštinu. Pritom osobito valja čuvati i razvijati hrvatski jezik te paziti na njegovu pravilnu primjenu“ (MZOS cilj 2). U tom smislu zanimljiva je i odredba iz Pravilnika o uvjetima za izbor u znanstvena zvanja (NVZVOTR odjeljak 4) koja propisuje da za izbor u znanstveno zvanje znanstveni suradnik „pristupnik mora imati najmanje jedan samostalan znanstveni rad objavljen na hrvatskom standardnom jeziku, a za izbor u svako više zvanje pristupnik mora imati najmanje jedan znanstveni rad objavljen na hrvatskom standardnom jeziku nakon prethodnog izbora“ (NVZVOTR odjeljak 5). Slična odredba 
regulira i izbor u području humanističkih znanosti. U više navrata znanstvenici su javno izrazili skepsu da takvo normiranje daje pozitivan vjetar očuvanju „malih jezika“ u znanosti (Jurić; Rudež).

Postavlja se pitanje kako male nacionale zajednice mogu izbjeći marginalizaciju u procesu globalizacije, pri čemu ne treba izostati asertivna pozicija (Đurčinov 316). Hrvatski jezik kao jezik znanstvenog komuniciranja ima tri specifičnosti (Hebrang Grgić 7-8). Prva ga određuje kao jezik brojčano male znanstvene zajednice te kao takav ne može postići vidljivost kakvu pruža engleski jezik. Druga specifičnost vezana je uz ekonomska ograničenja s kojima se hrvatski znanstvenici susreću naspram kolega iz razvijenijih zemalja, dok je treća „nekomercijalnost izdavača znanstvenih časopisa“ (Hebrang Grgić 8).

\section{4. (Ne)vidljivost hrvatskih filozofa}

Navedeni teorijski okvir daje nam temelj za postavljanje triju hipoteza. Prva $(\mathrm{H} 1)$ tvrdi kako će u specijaliziranim rječnicima i enciklopedijama iz filozofije postojati podzastupljenost autora iz Hrvatske. Ovdje ćemo razlikovati dvije skupine tercijarnih izvora: autorske i kolaborativne (Wikipedia). Druga (H2) tvrdi kako će natuknice, ako i postoje, biti objavljene na malom broju jezika. Treća (H3) tvrdi kako se očekuje izvjesna količina netočnih informacija u natuknicama.

Za analizu smo uzeli sljedeće reference:

Randal Collins „Sociology of Philosophies ${ }^{\$ 3]}$

Edward Craig i Luciano Floridi (ur.) „Routledge Encyclopedia of Philosophy CDROM“

E. Craig (ur.) „The Concise Routledge Encyclopedia of Philosophy“

E. Craig (ur.) „The Shorter Routledge Encyclopedia of Philosophy“

Donald M. Borchert (ur.) „Encyclopedia of Philosophy“

Jonathan Rée i J. O. Urmson (ur.) „The Concise Encyclopedia of Western Philosophy“ Hans Jörg Sandküler (ur.) „Enzyklopädie Philosophie“ Jürgen Mittelstraß (ur.) „Enzyklopädie Philosophie Und Wissenschaftstheorie“ Sahotra Sarkar i Jessica Pfeifer (ur.) „Philosophy of Science. An Encyclopedia“ 
T. Frolov (ur.) „Dictionary of Philosophy / Filosofskií slovar“

Simon Blackburn (ur.) „The Oxford Dictionary of Philosophy“

Thomas Mautner (ur.) „The Penguin Dictionary of Philosophy“

Edward N. Zalta (ur.) „Stanford Encyclopedia of Philosophy“

James Fieser i Bradley Dowden (ur.) „Internet Encyclopedia of Philosophy“

Wikipedia, višejezična izdanja

Napravljen je popis 22 hrvatska filozofa, povijesna i živuća. U stvaranju popisa vodili smo se imenima iz enciklopedijske natuknice iz Routledge enciklopedije (Lazović i Pavković) te ga proširili s nekoliko relevantnih živućih filozofa ${ }^{[4]}$ Za svaki od navedenih tercijarnih izvora provjerili smo postoji li enciklopedijska ili rječnička natuknica o filozofu s popisa te u koliko se drugih natuknica u istom izvoru pojavljuje spomen na istog filozofa. U Tablici 1 prikazani su rezultati pretrage za uredničke enciklopedije i rječnike. Iz metodoloških razloga odvojili smo obradu uredničkih enciklopedija od različitih jezičnih izdanja Wikipedije. Razlog je autoritativnost; iako je Wikipedija načelno pouzdana referenca, izostanak centraliziranog nadzora nad tekstom i mogućnost beskonačnih dodatnih intervencija u tekst jasno razlikuje tu enciklopediju od ostalih. Dvije uvrštene internetske specijalizirane enciklopedije, Stanfordska... (Zalta) i Internetska... (Fieser i Dowden) imaju jasno označene autore pojedinih članaka, pa su time svrstane u prvu skupinu.

Podaci su poražavajući: jedina dva filozofa koja imaju vlastite natuknice su Frane Petrić i Ruđer Bošković. 


\begin{tabular}{|c|c|c|c|c|c|c|c|c|c|c|c|c|c|}
\hline & Collins & REP & CREP & CWEP & GEP & PSE & Sand. & Mitt. & PDP & ODP & SDP & SEOP & IEP \\
\hline Đuro Arnold & 0 & 0 & 0 & 0 & 0 & 0 & 0 & 0 & 0 & 0 & 0 & 0 & 0 \\
\hline Albert Bazala & 0 & 1 & 0 & 0 & 0 & 0 & 0 & 0 & 0 & 0 & 0 & 0 & 0 \\
\hline Ruđer Bošković & 0 & 6 & 0 & 0 & $\Delta$ & 3 & 0 & $\boldsymbol{\Delta}$ & 1 & $\boldsymbol{\Delta}$ & 0 & 4 & 4 \\
\hline Herman Dalmatin & 1 & 2 & 0 & 0 & 1 & 0 & 0 & 4 & 0 & 0 & 0 & 1 & 0 \\
\hline Markantun de Dominis & 0 & 1 & 0 & 0 & 0 & 0 & 0 & 0 & 0 & 0 & 0 & 0 & 0 \\
\hline Juraj Dragišić & 0 & 1 & 0 & 0 & 0 & 0 & 0 & 0 & 0 & 0 & 0 & 0 & 0 \\
\hline Heda Festini & 0 & 0 & 0 & 0 & 0 & 0 & 0 & 0 & 0 & 0 & 0 & 0 & 0 \\
\hline Ljudevit Gaj & 0 & 1 & 0 & 0 & 0 & 0 & 0 & 0 & 0 & 0 & 0 & 0 & 0 \\
\hline Milan Kangrga & 0 & 1 & 0 & 0 & 1 & 0 & 0 & 1 & 0 & 0 & 0 & 0 & 0 \\
\hline Juraj Križanić & 0 & 1 & 0 & 0 & 0 & 0 & 0 & 0 & 0 & 0 & 0 & 0 & 0 \\
\hline Franjo Marković & 0 & 1 & 0 & 0 & 0 & 0 & 0 & 0 & 0 & 0 & 0 & 0 & 0 \\
\hline Nenad Miščević & 0 & 1 & 0 & 0 & 4 & 0 & 0 & 0 & 0 & 0 & 0 & 4 & 0 \\
\hline Gajo Petrović & 0 & 1 & 0 & 0 & 3 & 0 & 0 & 3 & 0 & 0 & 0 & 0 & 0 \\
\hline Frane Petrić & 1 & $\Delta 8$ & $\Delta 3$ & 0 & $\boldsymbol{\Delta}$ & 0 & 1 & $\boldsymbol{\Delta}$ & 0 & 0 & 0 & $\boldsymbol{\Delta}$ & 3 \\
\hline Rikard Podhorsky & 0 & 1 & 0 & 0 & 0 & 0 & 0 & 0 & 0 & 0 & 0 & 0 & 0 \\
\hline Zvonko Richtman & 0 & 1 & 0 & 0 & 0 & 0 & 0 & 0 & 0 & 0 & 0 & 0 & 0 \\
\hline Neven Sesardić & 0 & 1 & 0 & 0 & 0 & 0 & 0 & 1 & 0 & 0 & 0 & 3 & 0 \\
\hline J. J. Strossmayer & 0 & 1 & 0 & 0 & 0 & 0 & 0 & 0 & 0 & 0 & 0 & 0 & 0 \\
\hline Vanja Sutlić & 0 & 1 & 0 & 0 & 0 & 0 & 0 & 0 & 0 & 0 & 0 & 0 & 0 \\
\hline Matija Vlačić Ilirik & 0 & 1 & 0 & 0 & 2 & 0 & 2 & 1 & 0 & 0 & 0 & 1 & 0 \\
\hline Pavao Vuk-Pavlović & 0 & 1 & 0 & 0 & 0 & 0 & 0 & 0 & 0 & 0 & 0 & 0 & 0 \\
\hline Stjepan Zimmermann & 0 & 0 & 0 & 0 & 0 & 0 & 0 & 0 & 0 & 0 & 0 & 0 & 0 \\
\hline
\end{tabular}

Tablica 1. Prikaz zastupljenosti hrvatskih filozofa u specijaliziranim enciklopedijama i rječnicima. Legenda: Collins (Collins), REP (Craig i Floridi), CREP (Craig, The Concise), CWEP (Rée i Urmson), GEP (Borchert), PSE (Sarkar i Pfeifer), Sand. (Sandkühler), Mitt. (Mittelstraß), PDP (Mautner), ODP (Blackburn), SDP (Frolov), SEoP (Zalta), IEP (Fiesler i Dowden). Podaci za prvih pet stupaca preuzeti su iz: Ćirić 108.

Pri tome se Petrić spominje u 5 od 12 analiziranih izvora, a Bošković u samo 2. Jedini izvor koji nudi natuknice o obojici je Mittelstraßova enciklopedija. Kada pogledamo internetske izvore, postoji samo jedna natuknica, ona o Petriću u Stanfordskoj enciklopediji, ali njen autor nije hrvatski filozof. Ovakvi nalazi jasno upućuju na neophodnost većeg angažmana strukovne zajednice kako bi se povećala vidljivost hrvatskih filozofa u tercijarnim referencama. Zastupljenost u Wikipediji (u obzir su uzete sve jezične inačice) nešto je bolja - od 22 filozofa s popisa tek njih trojica nemaju natuknicu ni na jednom jeziku (Richtman, Zimmermann i Podhorsky). Time smo prvu hipotezu, o podzastupljenosti, barem empirijski poduprli. Naime, kako uvrštene enciklopedije ne posjeduju pojedinačnu natuknicu o filozofiji u Hrvatskoj, kao referentna točka za popis imena poslužila je natuknica iz REP (Lazović i Pavković). S malim proširenjem popisa imena, dobili smo popis o zastupljenosti u enciklopedijama i rječnicima koji pruža dvije informacije: prepoznatoj značajnosti pojedinog filozofa (posjeduje li eponimnu natuknicu) te općoj zastupljenosti (spominje li se filozof u nekoj drugoj natuknici). Samo dva imena s popisa daju poimeničnu prepoznatljivost manju od $10 \%$ (9.1\%), dok se opća zastupljenost može opisati distribucijom broja spomenutih filozofa u pojedinoj referenci (Slika 1). Medijan (2) i mod (1) dovoljna su indikacija podzastupljenosti. Najviše filozofa s 
našeg popisa spominje REP, njih 19, a ni jednog ne spominju CWEP (Rée i Urmson) i SDP (Frolov). Medijan i mod ostaju isti ako iz distribucije izbacimo ekstremni rezultat za REP, mijenja se samo raspon, s 19 pada na 7 .

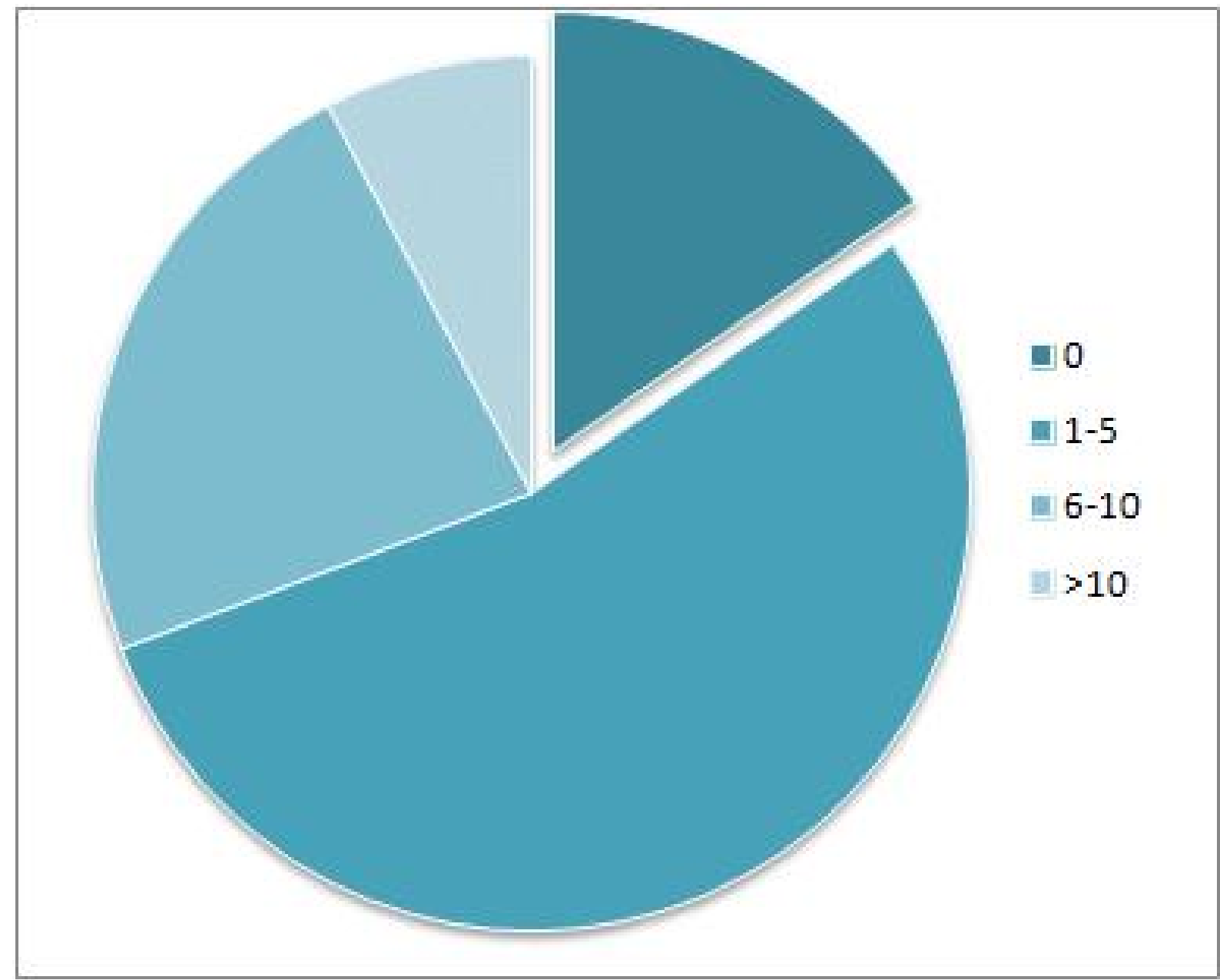

Slika 1. Distribucija broja spomenutih filozofa iz uzorka u analiziranim tercijarnim referencama. 


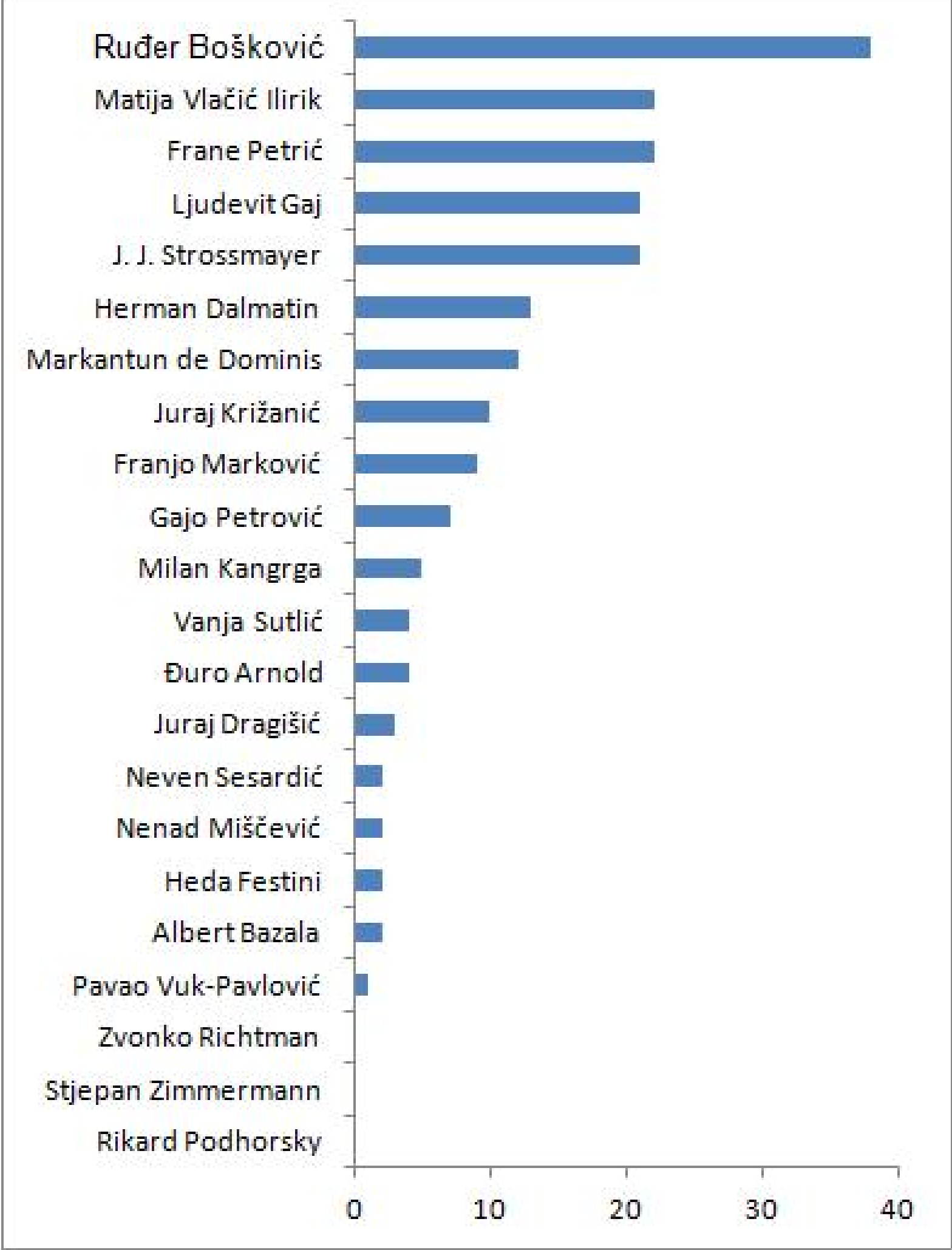

Slika 2. Broj eponimnih natuknica na različitim jezicima (izdanjima) Wikipedije za 22 hrvatska filozofa. 
Sljedeća je hipoteza o malom broju jezika natuknicâ u Wikipedija enciklopediji. Najviše se spominje Ruđer Bošković, koji ima 38 vlastitih natuknica na različitim jezicima. Slijede Matija Vlačić Ilirik i Frane Petrić s 22. Distribucija je prikazana na slici 2. Podatke o broju natuknica za pojedinog filozofa preuzeli smo s poveznica na danoj natuknici te ga provjerili i preko usluge Wikidata. [15]Druga se hipoteza može ilustrirati i slikom 3 na kojoj je prikazano koliko enciklopedijskih natuknica o hrvatskim filozofima s našeg popisa ima na pojedinom jeziku. 


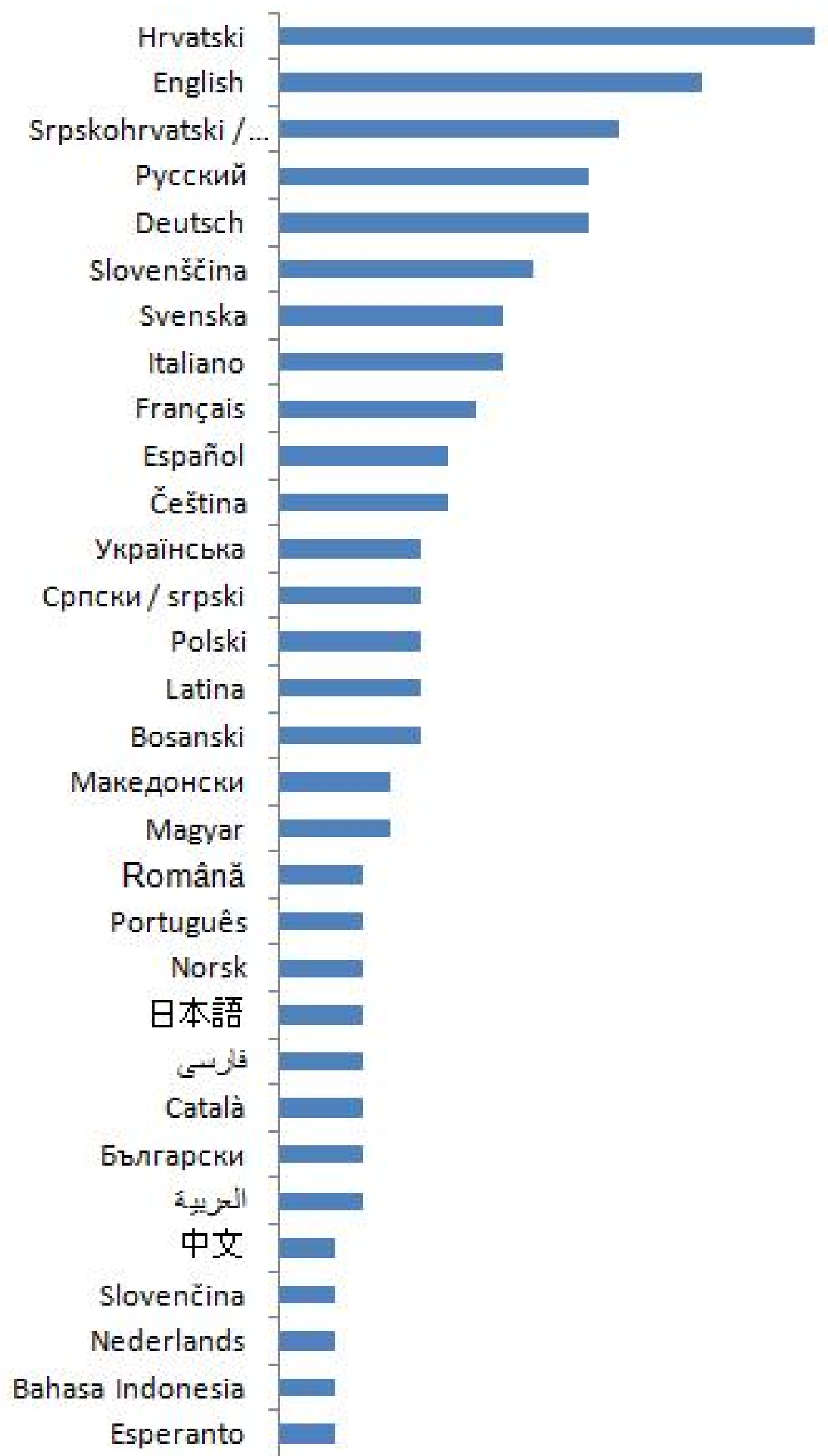


Najzastupljeniji je, očekivano, hrvatski jezik, s 19 natuknica, a onda slijedi engleski s njih 15. Wikipedija dopušta postojanje tzv. srpskohrvatskog jezika, koji je treći po zastupljenosti u našem uzorku (12 natuknica). Na četvrtom i petom mjestu su njemački i ruski jezik koji imaju 11 natuknica. Ovi nam podaci sugeriraju u kojem bi smjeru trebalo ići želimo li popraviti postojeće stanje podzastupljenosti. Donekle iznenađuje sedmo mjesto švedskog jezika, ispred nekih svjetskih jezika. Bara bra![]

[I6]Slika 3. Broj enciklopedijskih natuknica o hrvatskim filozofima na Wikipediji prema jeziku natuknice.

Treću hipotezu o netočnostima u enciklopedijskim i rječničkim natuknicama ilustrirat ćemo s nekoliko primjera. Važnost njenog isticanja je u konstatiranju potrebe za intervencijom stručnjaka za povijest filozofije u Hrvatskoj i promišljanju postupaka kontrole štete.

Kada je riječ o hrvatskoj filozofiji kao cjelini, ni jedan od analiziranih izvora ne donosi takvu natuknicu. Routledge enciklopedija... (Craig i Floridi) donosi članak o filozofiji kod Južnih Slavena (Lazović i Pavković) gdje se spominje niz hrvatskih autora. Barišić izvješćuje o kontekstualiziranju hrvatske filozofije kao dijelu talijanske, ugarske ili jugoslavenske filozofije i šire od prikladnog povijesnog razdoblja $(240,244)$. Kada je riječ o Frani Petriću, u REP urednici propuštaju povezati njegovu natuknicu (Ashworth) s onom o filozofiji kod Južnih Slavena (Lazović i Pavković) te ga identificiraju kao Talijana. Ista tvrdnja može se naći u Routledgeovoj povijesti filozofije (prema Barišić 248), dok Uberwegov Nacrt povijesti filozofije prepoznaje krivo mjesto rođenja - grad Clissa u Dalmaciji (prema Barišić 229).

\section{Kako popraviti stanje?}

Postojeće stanje daje za pravo osjećaju zabrinutosti - kako riješiti nesrazmjer doprinosa hrvatskih filozofa struci i njihovu podzastupljenost u suvremenim specijaliziranim tercijarnim publikacijama? Predlažemo višestupanjsko rješenje: (1) okrupnjavanje postojećih resursa; (2) ispravljanje postojećih unosa i stvaranje novih; (3) stvaranje višejezičnih istraživačkih kolekcija. 
Autori se bave područjem filozofije znanosti, odnosno filozofije i etike informacije te si ne umišljaju kompetencije za provođenje istraživanja iz povijesti hrvatske filozofske baštine. Vođeni iskustvima drugih istraživača na sličnim projektima, dajemo si za pravo ponuditi nekoliko preporuka kako poboljšati stanje (ne)vidljivosti. Prva se odnosi na okrupnjavanje postojećih resursa. U Republici Hrvatskoj trenutno postoji sedam studija filozofije. Uvidom u važeće studijske programe (OzFSuZ 20-23; FFDI 45; OzFHS 407; OzFFFOS 2; OzFFFRI 113; OzFFFST 48) na studijima postoji barem jedan kolegij koji se bavi nekim segmentom povijesti filozofije u Hrvatskoj. Nadalje, pri HAZU postoji Zavod za povijest i filozofiju znanosti, a tu je i Institut za filozofiju, kojemu je dio misije upravo proučavanje hrvatske filozofske baštine (IzF, Statut čl. 9). Svakako postoji dovoljan broj stručnjaka iz područja koji mogu, uz zajednički napor, producirati kvalitetne tekstove o hrvatskim filozofima za tercijarne reference. S obzirom na značajan broj objavljenih publikacija na tu temu, posao se može obaviti u relativno kratkom razdoblju.

Druga faza odnosi se na ispravke postojećih enciklopedijskih i rječničkih natuknica o hrvatskim filozofima. Primjerice, u Routledge enciklopediji filozofije (Craig i Floridi), Franu Petrića se, u pripadajućoj natuknici, atribuira kao talijanskog filozofa (Ashworth) te ga se spominje u nekoliko drugih natuknica i propušta povezati s eponimom. Kako smo vidjeli u analizi, on je i jedini hrvatski filozof poimenice izdvojen u toj enciklopediji. Stanje nije bolje ni u drugim enciklopedijama, no u nekima je propuste lakše ispraviti jer postoje u mrežnom izdanju koje trpi višestruke nadopune. Upravo produkcija natuknica o značajnijim hrvatskim filozofima na svjetskim jezicima treba biti sljedeći korak. Dobro mjesto za početak je osiguravanje prijevoda stranice „Digitalna baština“ Instituta za filozofiju (IzF), gdje se mogu naći opće natuknice za 42 hrvatska filozofa. Nadalje, tu je i publikacija Studiae historiae philosophiae Croaticae gdje već postoje tekstovi na engleskom, francuskom i njemačkom jeziku koji se mogu iskoristiti kao polazište za stvaranje materijala u otvorenom repozitoriju.

Treća faza zahtijeva znatno više resursa i odnosi se na stvaranje višejezičnih istraživačkih kolekcija. One predstavljaju „digitalnu skupinu primarnih izvora i povezanih materijala koji podržavaju istraživanje izvjesne teme“ (Palmer 348). Kolekcije čine bazični elementi koji su po naravi digitalni i tematski povezani te imaju funkciju podrške istraživanju, poput klasične knjižnice. Skupljanje sadržaja je koherentno, tj. pomaže istraživanju dane teme, pri čemu je sadržaj 
heterogen po vrsti (primarne, sekundarne i tercijarne reference, različiti multimedijalni formati). Sadržaji su strukturirani, čime se omogućuju pretraživanje i analiza, no oni su i otvoreni skup s mogućnošću stalnog proširivanja sadržaja (prema Palmer 350-1). Nekoliko je primjera, poput višejezičnog korpusa Platonove Države (Ide 294), cjelokupne zbirke bilježaka Charlesa Darwina $(\mathrm{AMoNH})$ ili zbirke Wittgensteinovih spisa (WAB; WWA). Neki od projekata nude i interaktivnost koja pruža uvid u strukturu rada, poput umjetničke vizualizacije (Posavec i Mclnerny) Darwinova Podrijetla vrsta, ili interaktivne vizualizacije revizija za njenih prvih šest izdanja (FAI). Jedan smjer u kojem se projekt može razvijati je i analiza kompleksnih mreža osobnih interakcija i kocitatnosti, što može pojasniti kontekst djelovanja pojedinih autora unutar hrvatskih, ali i europskih kretanja (vidi Ćurko i Ćirić; Ćirić 80).

\section{Zaključak}

Kako možemo vidjeti, postoji značajno mjesto za povezanost digitalne humanistike i povijesti filozofije u Hrvatskoj. Nažalost, kada pogledamo dostupne suvremene tercijarne reference, očita je podzastupljenost. Tamo gdje i postoje poimenične enciklopedijske natuknice, potrebni su izvjesni ispravci. Autori su uvjerenja kako je racionalnim raspolaganjem dostupnih resursa moguće u kratkom vremenu uspješno odraditi kontrolu štete. Strukovna zajednica trebala bi se usmjeriti prema dugoročnom projektu produkcije relevantnih enciklopedijskih referenci na svjetskim jezicima kako bi se povećala međunarodna vidljivost značajnih imena iz hrvatske filozofske baštine.

\section{Bibliografija}

Amano, Tatsuya, i ostali. „Global Distribution and Drivers of Language Extinction Risk“. Proceeding of the Royal Society B, tom 281, izd. 1793, 2014, doi:10.1098/rspb.2014.1574.

AMoNH: American Museum of Natural History. Darwin Manuscript Project. American Museum of Natural History, www.amnh.org/our-research/darwin-manuscripts-project/editedmanuscripts/darwin-s-reading/reading-notebooks. Pristupljeno 1. velj. 2018.

Ashworth, E. J. „Patrizi Da Cherso, Francesco (1529-97)“. Routledge Encyclopedia of Philosophy, priredili Edward Craig i Luciano Floridi, Routledge, 1998. 
Barišić, Pavo. „U povijesnofilozofijskom obzoru recepcije“. Prilozi za istraživanje hrvatske filozofske baštine, izd. 57-58, 2003, str. 221-59.

Blackburn, Simon, ur. The Oxford Dictionary of Philosophy. Oxford University Press, 1996.

Borchert, Donald M., ur. Encyclopedia of Philosophy. 2. izd., Thomson Gale, 2006.

Busa, Roberto A. „Foreword: Perspectives on the Digital Humanities“. A Companion to Digital Humanities, priredila Susan Schreibman i ostali, Blackwell, 2004, str. xvi - xxii.

Collins, Randall. The Sociology of Philosophies: A Global Theory of Intellectual Change. 4th print, The Bellknap Press, 2002.

Crane, Greg. „Classics and the Computer: An End of the History“. A Companion to Digital Humanities, priredila Susan Schreibman i ostali, Blackwell, 2004, str. 46-55.

Craig, Edward, ur. The Concise Routledge Encyclopedia of Philosophy. Routledge, 2000.

Craig, Edward, ur. The Shorter Routledge Encyclopedia of Philosophy. Routledge, 2005.

Craig, Edward, i Luciano Floridi, ur. Routledge Encyclopedia of Philosophy v1.0. Routledge, 1998.

Ćirić, Josip. defragmentacije. Mala filozofija, 2017.

Ćurko, Bruno, i Josip Ćirić. „Juraj Dragišić - primjena socijalnih mreža u analizi povijesti hrvatske filozofije“. 15. simpozij Petrić i Renesansne filozofske tradicije, 24.-27. rujna 2008, Cres. Okrugli stol.

Domić Kunić, Alka. „Antička enciklopedistika - pojavnost i dosezi“. Arheol. rad. raspr., izd 17, 2015, str. 85-121.

Đurčinov, Milan. „Mogući pozitivni kulturni doprinos malih naroda u Evropi“. Europa i enciklopedija: kultura i kodifikacija, Pravni fakultet Sveučilišta u Zagrebu i Leksikografski zavod Miroslav Krleža, 2015, str. 313-18.

Eiteljorg, Harrison II. „Computing for Archaeologists“. A Companion to Digital Humanities, priredila Susan Schreibman i ostali, Blackwell, 2004, str. 20-30.

Ess, Charles. „Revolution? What Revolution?' Successes and Limits of Computing Technologies in Philosophy and Religion“. A Companion to Digital Humanities, Blackwell, 2004, str. 132-43. 
FAl: Fathom Information Design. The Preservation of Favoured Traces. Fathom Information Design, 2011, fathom.info/traces/. Pristupljeno 1. velj. 2018.

FFDI: Filozofski fakultet Družbe Isusove Sveučilišta u Zagrebu. Prijedlog preddiplomskog jednopredmetnog studija Filozofija. Filozofski fakultet Družbe Isusove Sveučilišta u Zagrebu, 2005, www.ffdi.hr/images/obavijesti/Microsoft\%20Word\%20-\%20FFDI_predd_jednopredmetni_fil.pdf. Pristupljeno 1. velj. 2018.

Fieser, James, i Bradley Dowden, ur. Internet Encyclopedia of Philosophy. University of Tennessee at Martin, 2016, www.iep.utm.edu/.

Floridi, Luciano. „What Is the Philosophy of Information?“ Cyber Philosophy: The Intersection of Computing and Philosophy, priredili James H. Moor i Terrell Ward Bynum, Blackwell, 2002, str. 117-38.

Fodor, Jerry. The Language of Thought. Harvester Press, 1975.

Frolov, Ivan Timofeevich. Dictionary of Philosophy / Filozofskií Slovar. Priredili Murad Saifulin i Richard R. Dixon, Progress Publishers, 1984.

Gehrmann, Siegfried, i Ivana Rončević. „Pojednojezičenje znanosti kao hegemonijalni projekt: europske perspektive i anglofone stvarnosti“. Filologija, izd. 65, 2015, str. 13-44.

Greenhalgh, Michael. „Art History“. A Companion to Digital Humanities, priredila Susan Schreibman i ostali, Blackwell, 2004, str. 31-45.

Haberland, Hartmut. „English - The Language of Globalism?“ RASK, izd. 30, 2009, str. 17-45. Hebrang Grgić, Ivana. „Komunikacija putem časopisa u hrvatskoj znanstvenoj zajednici“. Hrvatski znanstveni časopisi: Iskustva, gledišta, mogućnosti, priredila Ivana Hebrang Grgić, Školska knjiga, 2015, str. 7-12.

Hockey, Susan. „The History of Humanties Computing“. A Companion to Digital Humanities, priredila Susan Schreibman i ostali, Blackwell, 2004, str. 3-19.

Howard, Jennifer. „In Face of Professors' ,Fury, ' Syracuse U. Library Will Keep Books on Shelves“. The Chronicle of Higher Education, 11. prosinca 2009, www.chronicle.com/article/In-Face-ofProfessors-Fury/49133. Pristupljeno 1. velj. 2018. 
Ide, Nancy. „Preparation and Analysis of Linguistic Corpora“. A Companion to Digital Humanities, priredila Susan Schreibman i ostali, Blackwell, 2004, str. 289-305.

IzF: Institut za filozofiju. Digitalna baština. Institut za filozofiju, 2018, content.ifzg.hr/digitalnaBastina/digitalnaBastina.htm. Pristupljeno 1. velj. 2018.

IzF: Institut za filozofiju. Statut Instituta za filozofiju u Zagrebu. Institut za Filozofiju, 2014, www.ifzg.hr/dokumenti/Statut_Instituta_za_filozofiju.pdf. Pristupljeno 1. velj. 2018.

Jecić, Zdenko. „Nadnacionalni karakter internetskih enciklopedija“. Studia lexicographica: časopis za leksikografiju i enciklopedistiku, tom 9, izd. 5.2, 2011, str. 103-18.

Jurić, Hrvoje. Hrvoje Jurić: Politički cirkus Ministarstva znanosti je opasan: Intervju s Ladislavom Tomičićem. Novi list, 17. ožujka 2013, www.novilist.hr/Znanost-i-tehnologija/Znanost/Hrvoje-JuricPoliticki-cirkus-Ministarstva-znanosti-je-opasan?meta_refresh=true. Pristupljeno 1. velj. 2018.

Lazović, Živan, i Aleksandar Pavković. „South Slavs, Philosophy of“. Routledge Encyclopedia of Philosophy, priredili Edward Craig i Luciano Floridi, Routledge, 1998.

Mautner, Thomas, ur. The Penguin Dictionary of Philosophy. 2. izd., Penguin Books, 2005.

McCulloch, Warren S., i Walter Pitts. "A logical calculus of the ideas immanent in nervous activity“. Bulletin of Mathematical Biophysics, tom 5, izd. 4, 1943, str. 11533.

Miloš, Irena. „Jezik i identitet. Što nam o tome govore baba i deda?“ Hrvatski jezik $\square$ nanstvenopopularni časopis za kulturu hrvatskoga jezika, tom 1, izd. 1, 2014, str. 12-13.

Mittelstraß, Jürgen, ur. Enzyklopädie Philosophie Und Wissenschaftstheorie. Verlag J. B. Metzler, 2004.

MZOS: Ministarstvo znanosti, obrazovanja i sporta. „Strategija znanosti, obrazovanja i tehnologije u Republici Hrvatskoj“. Narodne novine, tom 124/2014, 2014.

Nikolić, Davor. „Digitalna humanistika i nacionalna filologija: o mogućim implikacijama računalnoga obrata“. Croatica: časopis za hrvatski jezik, književnost i kulturu, tom 60, izd. 40, 2016, str. 75-87. NVZVOTR: Nacionalno vijeće za znanost, visoko obrazovanje i tehnološki razvoj. „Pravilnik o uvjetima za izbor u znanstvena zvanja“. Narodne novine, tom 28/2017, 2017. 
OzFFFOS: Odsjek za filozofiju Filozofskog fakulteta Sveučilišta J. J. Strossmayera u Osijeku. Filozofija - preddiplomski studij (dvopredmetni studij) izvedbeni nastavni plan. Filozofski fakultet Sveučilišta J. J. Strossmayera u Osijeku, 2016, www.ffos.unios.hr/download/1-preddiplomski.doc. Pristupljeno 1. velj. 2018.

OzFFFRI: Odsjek za filozofiju Filozofskog fakulteta Sveučilišta u Rijeci. Plan i program sveučilišnoga preddiplomskoga dvopredmetnog studija filozofije. Filozofski fakultet u Rijeci, 2015, www.ffri.uniri.hr/files/studijskiprogrami/2015-2016/FIL_program_preddipl_2015-2016.pdf. Pristupljeno 1. velj. 2018.

OzFFFST: Odsjek za filozofiju Sveučilišta u Splitu. Elaborat o studijskom programu. Preddiplomski sveučilišni studij filozofije (dvopredmetni). Filozofski fakultet Sveučilišta u Splitu, 2015, www.ffst.unist.hr/_download/repository/FIL_preddiplomski.pdf. Pristupljeno 1. velj. 2018.

OzFHS: Odjel za filozofiju Hrvatskih studija Sveučilišta u Zagrebu. Informacijski paket ECTS-a za akademsku godinu 2013/2014. Red predavanja - Preddiplomski studij. Hrvatski studiji Sveučilišta u Zagrebu, 2014, www.hrstud.unizg.hr/images/50014307/Filozofija-Program-P-D.pdf. Pristupljeno 1. velj. 2018.

OzFSuZ: Odjel za filozofiju Sveučilišta u Zadru. Program diplomskog studija filozofije. Sveučilište u Zadru, 2005, www.unizd.hr/Portals/24/Filozofija_diplomski.pdf. Pristupljeno 1. velj. 2018.

Palmer, Carole L. „Thematic Research Collections“. A Companion to Digital Humanities, priredila Susan Schreibman i ostali, Blackwell, 2004, str. 348-65.

Pašalić, Magda, i Sanja Marinov. „The English Language and Globalization“. Školski vjesnik, tom 57 , izd. 3-4, 2008, str. 249-58.

Pollock, John L. „Procedural Epistemology“. The Digital Phoenix: How Computers Are Changing Philosophy, priredili Terrell Ward Bynum i James H. Moor, Blackwell, 1998, str. 17-36.

Posavec, Stefanie, i Greg Mclnerny. (En)tangled Word Bank. 2011, www.stefanieposavec.com/entangled-word-bank/?rq=darwin. Pristupljeno 1. velj. 2018.

Putnam, Hillary. Mind, Language and Reality, Philosophical Papers, Volume 2. Cambridge University Press, 1975. 
Ravlić, Slaven. „Enciklopedija kao socijalna utopija“. Studia lexicographica: časopis za leksikografiju i enciklopedistiku, tom 8, izd. 5.1, 2011, str. 44-56.

Rée, Jonathan, i J. O. Urmson, ur. The Concise Encyclopedia of Western Philosophy. 3. izd., Routledge, 2005.

Rudež, Tanja. „Je li obveza pisanja radova na hrvatskom diskriminacija? Znanstvenici podijeljeni...“ Jutarnji list, 04. avgust 2016, www.jutarnji.hr/life/znanost/je-li-obveza-pisanja-radova-nahrvatskom-diskriminacija-znanstvenici-podijeljeni.../1281365/. Pristupljeno 1. velj. 2018. Sandkühler, Hans Jörg, ur. Enzyklopädie Philosophie. Felix Meiner Verlag, 2010. Sarkar, Sahotra, i Jessica Pfeifer, ur. The Philosophy of Science. An Encyclopedia. Routledge, 2006.

Schnapp, Jeffrey, i Todd Presner. The Digital Humanities Manifesto 2.0. 2009, www.humanitiesblast.com/manifesto/Manifesto_V2.pdf. Pristupljeno 1. velj. 2018.

Searle, John. „Minds, Brains and Programs“. The Behavioral and Brain Sciences, tom 3, izd. 3, 1980, str. 41724, doi: 10.1017/S0140525X00005756.

Steinhart, Eric. „Digital Metaphysics“. The Digital Phoenix: How Computers Are Changing Philosophy, priredili Terrell Ward Bynum i James H. Moor, Blackwell, 1998, str. 117-34.

Tomić, Marijana. „Digitalna humanistika kao izazov: promjena paradigme istraživanja u humanistici i praksa digitalizacije“. Festival digitalizacije, 20.-21. travnja 2015, Zagreb. Predavanje.

Turing, Alan. „Computing Machinery and Intelligence“. Mind, tom LIX, izd. 236, 1950, str. 43360, doi: $10.1093 / \mathrm{mind} /$ LIX.236.433.

UNESCO, Organizacija za obrazovanje, znanost i kulturu. Univerzalna deklaracija UNESCO-a o kulturnoj različitosti. UNESCO, 2001, www.unesco.org/fileadmin/MULTIMEDIA/HQ/CLT/diversity/pdf/declaration_cultural_diversity_hr.pdf. Pristupljeno 1. velj. 2018.

Vujić, Antun. „Europa i enciklopedija: kodifikacija i kultura“. Europa i enciklopedija: kultura, i kodifikacija, priredio Vlaho Bogišić, Pravni fakultet Sveučilišta u Zagrebu i Leksikografski zavod Miroslav Krleža, 2015, str. 11-19, bib.irb.hr/datoteka/558854.Europa_i_enciklopedija.pdf. 
WAB: University of Bergen. The Wittgenstein Archives at the University of Bergen. University of Bergen, 2017, wab.uib.no/. Pristupljeno 1. velj. 2018.

Wooldridge, Russon. „Lexicography“. A Companion to Digital Humanities, priredila Susan Schreibman i ostali, Blackwell, 2004, str. 69-78.

WWA: University of Helsinki. The von Wright and Wittgenstein Archives. University of Helsinki, 2006, www.helsinki.fi/wwa/projects.htm. Pristupljeno 1. velj. 2018.

Zalta, Edward N., ur. Stanford Encyclopedia of Philosophy. Metaphysics Research Lab, Center for the Study of Language and Information, Stanford University, 2016, plato.stanford.edu/. 
[1] Ovdje prikazani rezultati prezentirani su prvi put na znanstvenoj konferenciji 26. Dani Frane Petrića - Hrvatska filozofija u interakciji i kontekstu, održanoj na Cresu od 27. do 30. rujna 2017. [2] Među znamenitije trenutke te interakcije mogu se navesti rad Alana Turinga na matematičkom modelu računala, ranim neuralnim mrežama i postavljanje kriterija umjetne inteligencije, formalizam neuralnih mreža Warrena S. McCullocha i Waltera Pittsa, teorija modularnosti uma Jerryja Fodora, pristup slabe i jake umjetne inteligencije Johna Searlea, teorija tip-tip identitea Hillary Putnam te filozofija informacije Luciana Floridija.

[3] Collinsova je knjiga izvorna znanstvena studija, a ne tercijarna referenca. Uključena je u analizu zato što predstavlja sveobuhvatan pregled svjetske povijesti filozofije iz perspektive sociologije i analize kompleksnih mreža osobnih interakcija među filozofima. U tom kontekstu, zanimljivo je vidjeti gdje se i koliko spominju pojedini hrvatski autori.

[4] Inicijalni popis (Lazović i Pavković) tvore (abecedno): Albert Bazala, Ruđer Bošković, Markantun de Dominis, Juraj Dragišić, Ljudevit Gaj, Milan Kangrga, Juraj Križanić, Franjo Marković, Nenad Miščević, Gajo Petrivić, Frane Petrić, Rikard Podhorsky, Zornko Richtman, Neven Sesardić, J. J. Strossmayer, Vanja Sutlić, Matija Vlačić llirik, Pavao Vuk-Pavlović. Dodani su: Đuro Arnold, Herman Dalmatin, Heda Festini i Stjepan Zimmerman. Dakako, popis se mogao nastaviti, no autori su se odlučili zaustaviti na pola puta do smisla „Života, Svemira i Svega Ostalog“ (Adams 66). Nismo željeli da kriterij isključivanja bude samo biološka činjenica, pa smo se odlučili i za nekoliko živućih, ali umirovljenih imena.

[5] Švedski „Izvrsno!“ (doslovce: „samo dobro“). 